\title{
Building a Strong Front Against the COVID-19 Pandemic: Family Health Nursing
}

\section{COVID-19 Salgınına Karşı Güçlü Bir Cephe: Aile Sağlığı Hemşireliği}

\author{
Rıdvan Dogan *1,2, Saime Erol ${ }^{3}$, Kamer Gür ${ }^{4}$
}

\begin{abstract}
With the spread of the pandemic all over the world, social isolation is applied as a precaution and people spend most of their time at home with their families. Therefore, the responsibilities of the family health nurse are increasing. During this period, family health nurses provide services in pregnancy follow-up, newborn care and follow-up, care of individuals with chronic diseases, family education, vaccination, and quarantine measures. It has been observed that there has been a significant increase in workloads since vaccinations are carried out in family health centers and people prefer family health centers instead of crowded hospital environments. This article aims to discuss the role and importance of family health nurses providing primary health care in many aspects of health protection and development in Turkey and the world during the pandemic period.
\end{abstract}

Key words: Family nursing, home care, COVID-19

\section{ÖZET}

Salgının tüm dünyaya yayılmasıyla birlikte sosyal izolasyon önlem olarak uygulanmakta ve insanlar zamanlarının çoğunu evde aileleriyle geçirmektedir. Bu nedenle aile sağlığı hemşiresinin sorumlulukları artmaktadır. Bu dönemde aile sağlığı hemşireleri, gebelik takibi, yenidoğan bakımı ve takibi, kronik hastalığı olan bireylerin bakımı, aile eğitimi, aşılama ve karantina önlemleri konularında hizmet vermektedir. Pandemiden önce yoğun olarak sürdürülen bu hizmetler aşılamaların aile sağllğg merkezlerinde yapılması ve insanların kalabalık hastane ortamı yerine aile sağlı̆̆ merkezlerini tercih etmeleri nedeniyle iş yüklerinde belirgin şekilde artış olduğu gözlenmiştir. Bu yazının amacı birinci basamak sağlık hizmeti veren aile sağlı̆̆ hemşirelerinin pandemi döneminde Türkiye'de ve dünyada sağlı̆ın korunması ve geliştirilmesine yönelik birçok cephedeki rolünü ve önemini tartışmaktır.

Anahtar kelimeler: Aile hemşireliği, evde bakım, COVID-19

Received / Geliş tarihi: 06.01.2021, Accepted / Kabul tarihi: 25.05.2021

${ }^{1}$ Faculty of Health Sciences, Uskudar University, ISTANBUL (ORCID: 0000-0003-2125-8767)

${ }^{2}$ Institute of Health Sciences, Marmara University, ISTANBUL (ORCID: 0000-0003-2125-8767)

${ }^{3}$ Faculty of Health Sciences, Marmara University, ISTANBUL (ORCID: 0000-0001-7752-605X)

${ }^{4}$ Faculty of Health Sciences, Marmara University, ISTANBUL (0000-0002-2424-323X)

*Address for Correspondence / Yazışma Adresi: Faculty of Health Sciences, Uskudar University, İSTANBUL-TÜRKIYE

E-mail: ridvan.dogan@uskudar.edu.tr

Tel:+90 5388864043

Dogan R, Erol S, Gur K. Building a Strong Front Against the COVID-19 Pandemic: Family Health Nursing. TJFMPC, 2021;15(4): 651-654.

DOI: $10.21763 /$ tjfmpc.926796 
The COVID-19 pandemic that was first identified in Wuhan, China, and then rapidly took hold of the world led to an increase in hospital bed occupancy rates as well as fatalities in many countries. Despite the various measures that were taken to fight the pandemic, it was seen that numerous countries suffered from a shortage of healthcare staff and hospital capacities were over whelmed. Hospital occupancy rates have also increased in our country, especially the patient load of intensive care services has increased. In addition, there has been an increase in the workload because healthcare workers are sick.

The rise in hospital occupancy rates resulted in patients with slight symptoms being sent home to continue to quarantine themselves in their home environment. Because of that the risk of a patient in quarantine transmitting the virus to other family members is very high.

Along with the spread of the illness around the world, social isolation is being implemented and people are spending the main part of their lives at home with their families.

While individuals are withdrawing from social life during the period of the pandemic, nurses are at battle in the frontlines. It has been witnessed that in many parts of the world, nurses are in an active struggle against the illness despite shortages in personal protective equipment. ${ }^{1}$ In our country, there was also a shortage of protective equipment in family health centers in the early stages of the pandemic. ${ }^{2}$ This paper aims to discuss the role and significance of the family health nurse in terms of protecting and improving family health by responding to the health needs of pregnant and puerperal women, supervising the care and followup of newborns, of individuals with chronic conditions as well as people who are infected.

Firstly, home visits provide the opportunity to evaluate individuals in the home setting. This makes it possible to educate individuals and their families about preventative and health-improving behavior. By achieving this goal, all members of the family are encouraged to share the responsibility of protecting their health. At the same time, home visits enable an assessment of the health risks present in the home environment. ${ }^{3}$ Home care visits are carried out to address the health issues and needs of family members with chronic illnesses, HIV, tuberculosis, and other infectious diseases. ${ }^{4}$ Home visits under the auspices of family health services have gained even more significance in this period of the COVID-19 pandemic. In these days of the pandemic, family health nurses, equipped with the necessary protective apparatus, are making home visits to provide families with useful training regarding isolation and quarantine, thereby contributing to raising levels of knowledge and awareness about the pandemic, reducing anxieties, and minimizing the risk factors related to the environment, nutrition, hygiene, and contact.

In situations that resources are unavailable for home visits, the adoption of innovative applications is of great importance. Ensuring the use of online contacts and tele-health services contributes to keep the infection under control. ${ }^{5}$ The internet could be used for this purpose to provide highly effective group education to more people in a shorter space of time.

Turkey's family health and public health nurses are playing a crucial role in this period of the pandemic. Individuals who have been discharged from the hospital to continue treatment at home during the COVID-19 outbreak are followed up by the family health centers for two weeks. During this time, patients are called by phone, and a home visit is implemented whenever necessary. ${ }^{6}$ If an individual under observation is determined to be symptomatic, they are admitted into a hospital. The Ministry of Health Science Committee has issued guidelines for monitoring patients at home in this period. ${ }^{7}$ The Turkish Association of Nurses has published a guidebook titled "COVID-19 Nurses" Training Manual \& Care Algorithms and Monitoring of Patients Diagnosed/Suspected of Contracting COVID-19. ${ }^{8}$

COVID-19 does not only pose a problem in terms of contagion. Because of the decline in the provision of other healthcare services, it is believed that the public health issues that existed before the pandemic will eventually appear before us with more intensity. Child abuse, mother and child health, domestic violence, public mental health, healthcare for high-risk groups in the population, geriatric health are matters that have not received adequate attention from health service providers in the time of the pandemic, a fact that will increase the force of its destructive effects.

In our country, patients who hesitate to enter the crowded hospital environment due to the pandemic have turned to family health centers to meet their health and care needs. The workload of physicians and nurses working in family health centers increased due to the density experienced in 2nd and 3rd level health institutions and the inability of the appointment system to meet the demand. ${ }^{2}$

Since children can undergo the infection asymptomatically or recover after having only light symptoms, the risk of their being carriers is high. ${ }^{9}$ Children in contact with the family need to be scanned with isolation measures being put in place. 
Also, during this time when children are living at home, away from the scrutiny of their teachers at school, healthcare workers need to become more conscientious about monitoring children that may possibly fall victim to child abuse.

Pregnant women are susceptible to viral infections and display immunological responses. The stay-at-home policies implemented to reduce the spread of the COVID-19 pandemic may present a risk for pregnancy. Pregnancy commonly entails certain difficulties leading to postpartum depression and even domestic violence. Additionally, pregnant women may have reservations about benefiting from healthcare services. ${ }^{10}$ In our country, pregnancy follow-up continued in family health centers during the pandemic period. The follow-up and counseling services of the pregnant women who could not come to the family health center were provided by phone. ${ }^{2}$

The group to be most affected by the infection is the elderly. Social support provided to older adults has dwindled in this period of the virus, giving rise to a heightened risk of depression in this group, a reduction in access to medical aid, with hospitalization needs being postponed outside of emergency circumstances. ${ }^{11}$ Unfortunately, aging adults are likely to have hearing difficulties and are generally unfamiliar with the use of technology, making it challenging to reach this segment of the population by telephone or video conference. The home-hospital model and home care methods have been suggested in response to all of these circumstances. $^{12}$

Prior to the pandemic, it had been reported that home visits made by nurses prove to be effective in the fight to curb domestic violence. ${ }^{13}$ Unemployment, insufficient social support, stressinducing social events are risk factors for domestic violence. ${ }^{14}$ As people retreated into their homes in social isolation, an increase was seen in acts of violence in the home environment. It has been noted that in addition to their contribution to protecting domestic violence victims from the virus, family health nurses can play a significant role in preventing these victims from experiencing continued violence at home. The family health nurse should collaborate with other related institutions and organizations to evaluate the community in which they work for signs of domestic risks. The first people to realize the existence of domestic problems is usually the neighbors. The family health nurse should cooperate with members of the community to raise awareness and ensure that neighbors do not remain silent.

Health literacy is recognized as being one of the most effective factors in fighting contagious diseases. In particular, pandemics that spread around the world necessitate community awareness and it is important to provide the public with correct information. ${ }^{15}$ If this necessity is not addressed, panic and psychological trauma may be witnessed among parts of the general public while others may tend to exhibit general indifference toward the pandemic. Both types of behavior will harm any efforts to fight the pandemic in the community. It is therefore our belief that family education has the potential of decreasing the spread of the virus and of minimizing the psychological and social damage that can be caused by the pandemic.

Additionally, families that have contracted the virus may feel afraid of being isolated from healthcare providers or the community itself. ${ }^{4}$ This is why families must be provided psychosocial support and the issue of stigmatization should be openly discussed.

This pandemic provided us with vast experience as a country. It showed us that the fight against health problems that concern a large part of the society cannot be carried out only in wellequipped hospitals. We feel that public health and family health nurses must take a more effective role in their contact with families and the community in the process of health education, preventative healthcare, early intervention, and healing.

Based on pandemic experience, the power of family health nurses in the provision of healthcare services has been proved and it is now imperative that the scope of their training be widened to include the family health matters described above, with the required legislative measures taken to broaden the range of their competences. At the same time, to ensure that these services are carried out at a high quality, the nurse-to-population ratio should be brought down from the 4000's to figures recommended by the OECD. We recommend that priority be given to the hiring of specialized public health nurses at the family health centers. We believe that this will prevent the overwhelming of resources and healthcare services at the hospitals in the event of disasters such as the present pandemic, ensuring that medical care is continued uninterruptedly. Furthermore, the increased need for primary care services has revealed that the role of a hospital cannot be limited to treatment but must be broadened to include preventative and health improvement endeavors that will contribute to pulling through a major public health-threatening outbreak with a minimum of loss.

\section{REFERENCES}

1. Jackson D, Bradbury-Jones C, Baptiste D, Gelling L, Morin K, Neville S, Smith G. D. Life 
in the pandemic: some reflections on nursing in the context of COVID-19. Journal of Clinical Nursing 2020;29:2041-2043

2. Güler S, Topuz İ, Ulusoy, F. COVID-19 Pandemisinde Aile Sağlığı Merkezi Çalışanlarının Deneyimleri. Halk Sağlığı Hemşireliği Dergisi 2020;2(3):143-151.

3. Kaakinen JR, Coehlo DP, Steele R, Robinson $\mathrm{M}$. Family health care nursing: Theory, practice, and research. FA Davis 2018:105-135.

4. Putra KWR. Home visits for applying family nursing: a perspective. Nurse and Health: Jurnal Keperawatan 2019;8(2):69-71.

5. Li DKT. Challenges and responsibilities of family doctors in the new global coronavirus outbreak. Family Medicine and Community Health 2020;8(1):e000333.

6. Yurt S. Aile Sağlığ 1 Hemşireliği Uygulamalarında COVID-19 Yönetimi. COVID-19 Pandemisi ve Halk Sağlığ1 Hemşireliği. Türkiye Klinikleri 2020;35-41.

7. COVID-19 (SARS-CoV2Enfeksiyonu) Temaslı Takakibi, Salgın Yönetimi, Evde Hasta İzlemi ve Fisyasyon (4.05.2021). T.C. Sağlık Bakanlığı. Halk Sağlığı Genel Müdürlüğü. https://covid19.saglik.gov.tr/TR66339/temasli-takibi-salgin-yonetimi-evdehasta-izlemi-ve-filyasyon.html(Date access:8.05.2021).

8. Covıd-19 Hemşire Eğitim Rehberi ve Bakım Algoritmaları. Türk Hemşireler Derneği (https://www.thder.org.tr/uploads/files/thdcovi d-2020-2.pdf(Date access:8.05.2021)
9. Lu X, Xing Y, Wong GW. COVID-19: lessons to date from China Archives of Disease in Childhood 2020;105:1146-1150.

10. Buekens P, Alger J, Bréart G, Cafferata ML, Harville E, Tomasso G. A call for action for COVID-19 surveillance and research during pregnancy. The Lancet Global Health 2020;8(7):e877-e878

11. Steinman MA, Perry L, Perissinotto CM. Meeting the care needs of older adults isolated at home during the COVID-19 pandemic. JAMA Internal Medicine 2020;180(6):819-820.

12. Nundy $S$, Patel KK. Hospital-at-Home to Support COVID-19 Surge-Time to Bring Down the Walls? JAMA Health Forum 2020;1(5):e200504-e200504

13. Ercan Sahin N, Aslan F, Emiroglu ON. Aile İçi Şiddetin Önlenmesi İçin Bir Model Önerisi: Halk Sağlığ 1 Hemşiresinin Ev Ziyareti ile Aile İzlemi. Journal of Hacettepe University Faculty of Nursing 2018;5(3):247-259.

14. Campbell AM. An increasing risk of family violence during the Covid-19 pandemic: Strengthening community collaborations to save lives. Forensic Science International: Reports 2020:100089, https://www.ncbi.nlm.nih.gov/pmc/articles/PM C7152912/ (Date access:8.05.2021)

15. Paakkari L, Okan O.COVID-19: health literacy is an underestimated problem. The Lancet Public Health, 2020:5(5);249-250. 